\title{
Cutaneous basal cell carcinoma arising within a keloid scar: a case report
}

This article was published in the following Dove Press journal:

OncoTargets and Therapy

2 August 2016

Number of times this article has been viewed

\author{
Maya Goder ${ }^{1, *}$ \\ Rachel Kornhaber ${ }^{2, *}$ \\ Daniele Bordoni ${ }^{3}$ \\ Eyal Winkler' \\ Josef Haik' \\ Ariel Tessone'
}

'Department of Plastic and Reconstructive Surgery, Sheba Medical Center, Tel Hashomer, Israel; ${ }^{2}$ School of Health Sciences, Faculty of Health, University of Tasmania, Sydney, NSW, Australia; ${ }^{3}$ Department of Senology, Ospedale Santa Maria della Misericordia Urbino, Urbino, Italy

*These authors contributed equally to this work
Correspondence: Maya Goder

Department of Plastic and Reconstructive Surgery, Sheba Medical Center,

Tel Hashomer, Emek HaEla St I,

5262I, Ramat Gan, Israel

Tel +97252888I555

Email maya.b.h@gmail.com

\begin{abstract}
Basal cell carcinomas (BCCs) are one of the most frequent cutaneous malignancies. The majority of BCCs are reported to occur on the auricular helix and periauricular region due to ultraviolet light exposure. Despite the frequency of BCCs, those that develop within scar tissue are rare, and the phenomenon of keloid BCCs has rarely been reported in the literature. Keloid collagen within BCCs is associated with morphoeiform characteristics, ulceration, or necrosis. Extensive keloid collagen is often seen in BCCs of the ear region, a site prone to keloid scarring. This article presents a rare case of a secondary tumor (BCC) which arose on top of a primary tumor (keloid scar) on the right auricle region in a healthy 23 -year-old female after an ear piercing 2 years prior. To our knowledge, the tumor described in this case, in contrast to keloidal BCCs, has never been reported in the literature.
\end{abstract}

Keywords: basal cell carcinoma, BCC, keloid scar, auricle, methylprednisolone acetate

\section{Introduction}

Basal cell carcinomas (BCCs) develop within the basal cell layer of the epidermis. ${ }^{1}$ They are one of the most frequent skin malignancies ${ }^{2,3}$ accounting for $75 \%-80 \%$ of all skin cancers, with $70 \%-80 \%$ of all BCCs occurring in the head and neck region. ${ }^{1}$ Furthermore, they are the most common type of malignancy of the ear. ${ }^{4}$ The majority of BCCs are reported to occur on the auricular helix and periauricular region due to exposure to ultraviolet light ${ }^{4}$ and may infiltrate the cartilage. ${ }^{4}$ Reports of an etiological relationship between prior trauma/scar tissue and the development of a BCC have been reported within the literature. ${ }^{3}$ To date, only five case reports of keloidal BCCs have been discussed in the literature..$^{5-9}$ Keloid collagen within BCCs is reported to be associated with morphoeiform characteristics, ulceration, or necrosis, with extensive keloid collagen seen in BCCs of the ear region, a site prone to keloid scarring. ${ }^{10}$ However, presented here, to our knowledge, is the first reported case of a secondary tumor (BCC) which arose on top of a primary tumor (keloid scar) on the right auricle region in a healthy 23 -year-old female after an ear piercing 2 years prior.

\section{Case report}

A 23-year-old female presented with ongoing management of a keloid scar on her right auricle with no relevant medical history. At 21 years of age, she had her ear pierced and developed a local infection that was treated initially with topical antibiotics. Subsequently, a keloid scar began to form (Figure 1). At first presentation, the lesion was observed to be a $1 \mathrm{~cm}$ red keloid scar on the mid-helix of the right auricle. Initially, $40 \mathrm{mg}$ of methylprednisolone acetate was injected locally and she was given a prescription for a pressure earing. Mechanical pressure is often used as a means to prevent or treat keloid scars. ${ }^{11}$ 


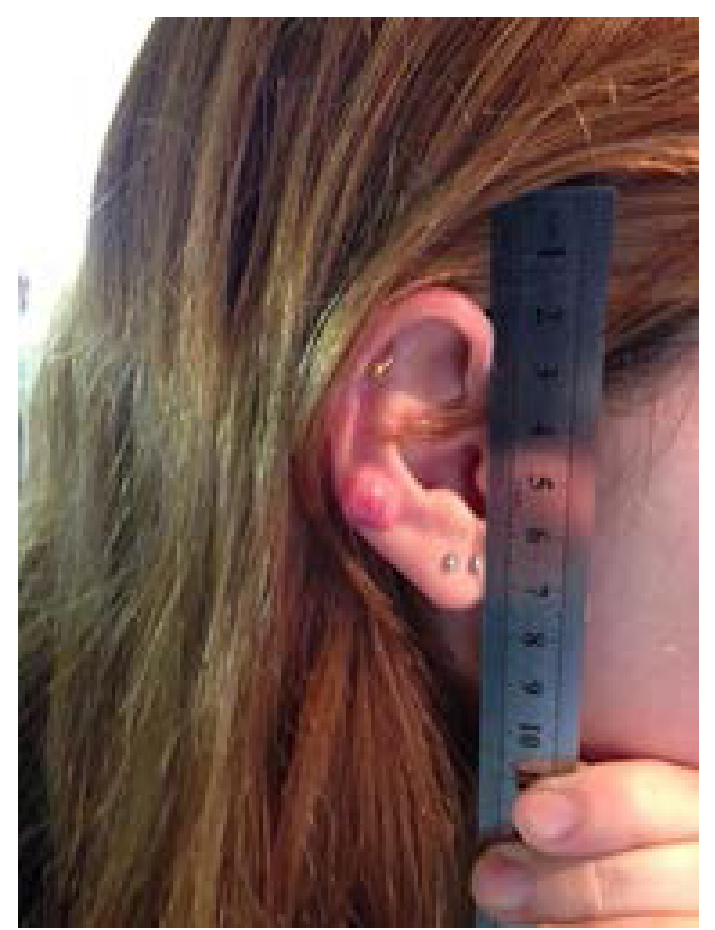

Figure I Keloid scar at first presentation.

At 1 month follow-up, during which time she had been wearing the pressure earing consistently, a slight improvement was observed with a mild reduction in the overall size of the keloid scar. Another injection of $40 \mathrm{mg}$ methylprednisolone acetate was given locally (Figure 2).

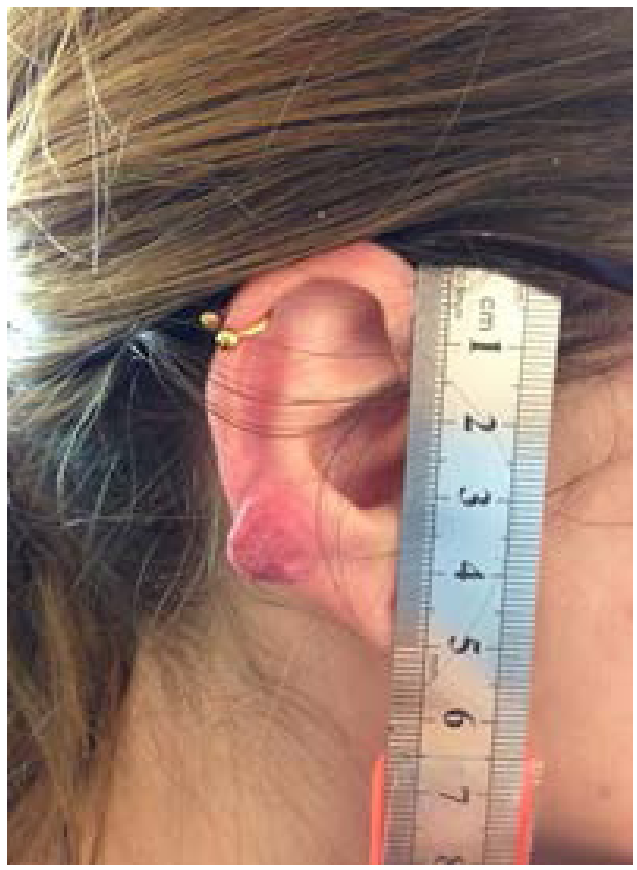

Figure 2 Follow-up after I month of wearing the pressure earing.
Four months after commencing the initial treatment, the patient presented again, and a 15\% improvement was observed with a reduction in the size of the keloid scar tissue to a diameter of $11 \mathrm{~mm}$. Again, the patient received another local injection of methylprednisolone acetate, but at a reduced dose of $20 \mathrm{mg}$. At 5 months follow-up, the base of the keloid was unchanged and remained at $11 \mathrm{~mm}$. However, the overall volume of the keloid had a flattened appearance as a result of the pressure earing. Again, the patient was administered another injection (locally) at the original dose of $40 \mathrm{mg}$ methylprednisolone acetate. A further 10 weeks on, the base of the keloid scar measured $10 \mathrm{~mm}$ and its height was reduced, with the total thickness of the right helix of the involved area measuring $8 \mathrm{~mm}$ as opposed to $7 \mathrm{~mm}$ in the opposite ear. Of significance, it was noted that part of the normal tissue in the involved area was replaced by the keloid over $1 \mathrm{~mm}$ thickness. The dose of $40 \mathrm{mg}$ methylprednisolone acetate was once again injected locally, in conjunction with the pressure earring (Figure 3).

A further 2 months on, the base of the keloid remained unchanged at $10 \mathrm{~mm}$; however, the total thickness of the helix reduced to $7 \mathrm{~mm}$. The posterior region of the helix remained a small flat patch, while the anterior of the helix presented with only minimal keloid content. At this time, another injection of $40 \mathrm{mg}$ methylprednisolone acetate was administered. After completing a year's treatment with methylprednisolone

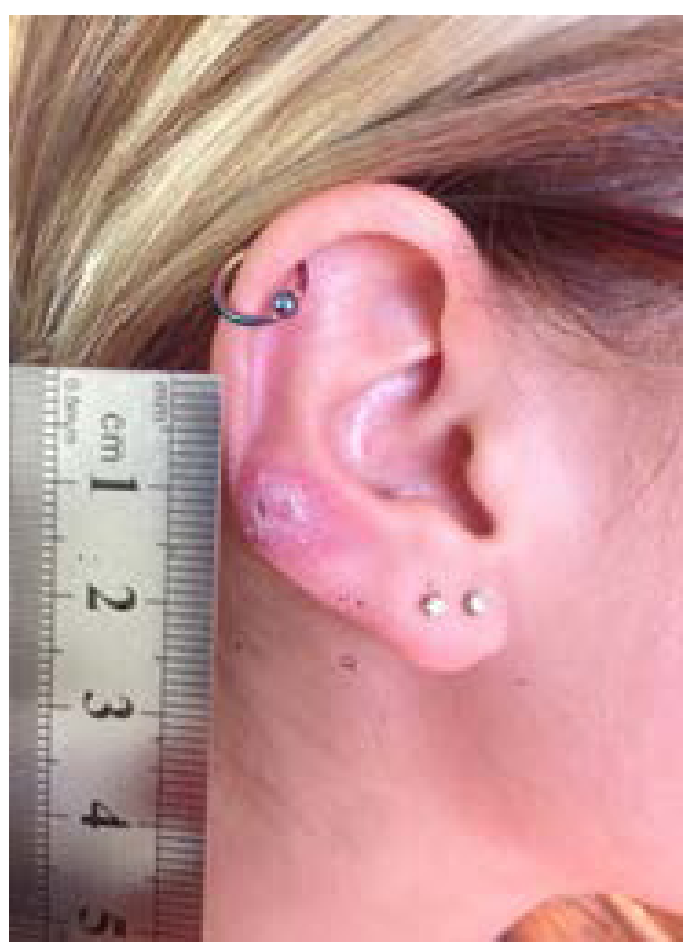

Figure 3 Keloid scar 5 months since the initial presentation with a flattened appearance. 


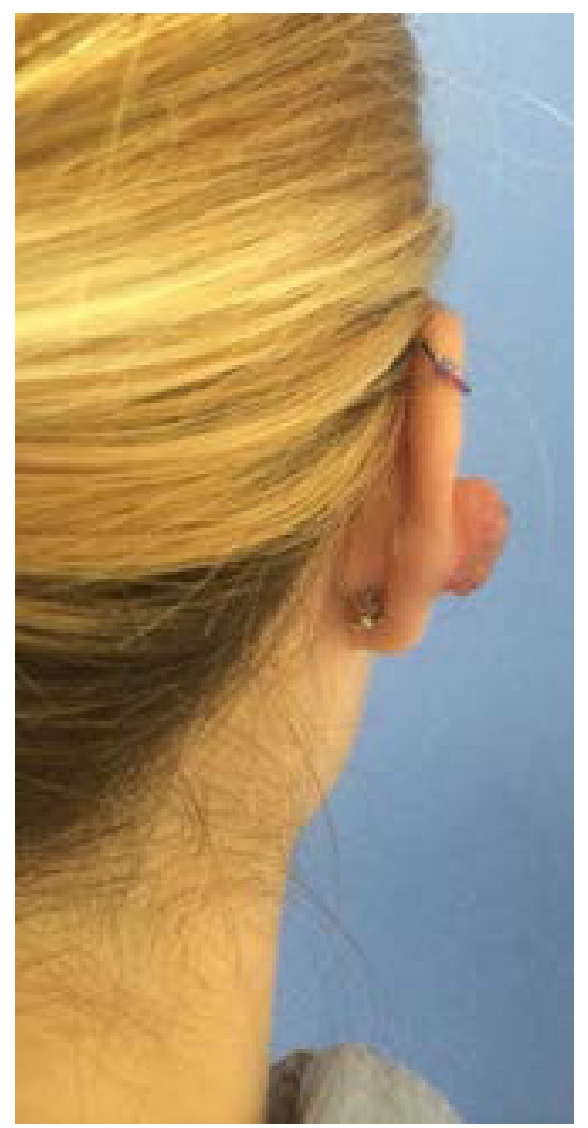

Figure 4 Rapid regrowth of keloid scar.

acetate and 3 years after the original piercing, the keloid scar became active again, appearing red and telangiectasic. A final local injection of $60 \mathrm{mg}$ methylprednisolone acetate was administered, resulting in no improvement with a further rapid growth in size (Figure 4).

It was decided to surgically excise the keloid lesion using wide margins, and subsequently, the growth was sent for histological examination. Histological examination determined that the lesion was consistent with keloid and had tiny foci of BCC arising from within. The patient provided informed written consent for the described procedures and the use of digital photography for the purposes of treatment, teaching and use in academic publications.

\section{Discussion}

The first known description of keloid was found in Smith Papyrus derived from ancient Egypt circa 3000 BC. ${ }^{12}$ The term keloid derives from the Greek word cheloid, chele $(\eta \lambda \eta)$ meaning a crab's claw and the suffix-oid, meaning like. ${ }^{4}$ Keloids are benign dermal fibroproliferative tumors ${ }^{13}$ that develop after the dermis experiences local trauma such as surgery, burns, laceration, tattoos, and infections. ${ }^{14}$
However, abnormal scarring remains poorly understood and is a consequence of surgical and traumatic wounds. ${ }^{15}$ Keloids are reported to be more frequent in certain ethnic groups and has an incidence of $15 \%-20 \%$ in the black population. ${ }^{16}$ Furthermore, these unique scars have been reported in patients with hereditary connective tissue disorders such as EhlersDanlos syndrome, in which keloids manifest as one of the clinical indicators. ${ }^{17}$ Keloid scar may develop anywhere; however, the ear is a common site for keloid formation, and the scar usually occurs after trauma or ear piercing, ${ }^{18}$ although there is limited data available for the treatment of helical rim keloids. ${ }^{19}$ The ear is reported to be a region with a propensity for the development of keloidal BCCs and is a site that is prone to the development of keloids in certain individuals..$^{10,18}$ This may be related to the frequent piercing of earlobes and the trauma and infection that can often ensue.

Requena et a $\mathrm{l}^{5}$ described a keloidal $\mathrm{BCC}$ for its striking and distinctive features, and from a clinical pathological basis, as a variant of a BCC deemed to be rare. ${ }^{10}$ However, this description has been refuted by others ${ }^{10}$ with a study identifying that keloid BCCs are not as rare as originally stated and therefore do not characterize a distinctive clinicopathological variant. ${ }^{10}$ Jones et $\mathrm{al}^{10}$ state that keloid BCCs are found in different histological kinds of BCCs with varying appearances. They found $1.6 \%$ of all BCCs had keloidal collagen in the stroma. ${ }^{10}$ Misago $^{9}$ who reported a case of a keloidal BCC, also found the stroma characteristically demonstrates the prominent keloidal, thickened collagen bundles and well-circumscribed keloidal collagen bundles that proliferated in a nodular form. Subsequently, it has been suggested that keloidal stromal reaction is due to local inflammatory changes secondary to necrosis or ulceration. ${ }^{10}$ Furthermore, it has been suggested there may be a correlation between keloid BCCs and the ear as a site for the development of keloidal stroma. ${ }^{10,20}$ However, the tumor described in this case, in contrast to a keloidal BCC, is rare and to our knowledge has never been reported in the literature. It is unique in that the common pathological process of a BCC developing necrosis and ulceration, which in turn cause inflammation and keloid scar formation, is reversed. In this case, we presented a keloid scar that has been dormant for 2 years, which improved under conservative treatment, and then underwent malignant transformation to a BCC. Since keloid scars can be considered a tumor, we in fact present a secondary tumor (BCC) which arises on top of a primary tumor (keloid scar). Furthermore, He et $\mathrm{al}^{13}$ and Meade et $\mathrm{al}^{21}$ demonstrate another example of unusual keloid behavior of eruptive keloids associated with cancer and the clinical importance of giving long-term dynamic consideration when following a keloid patient. 


\section{Conclusion}

Our case study highlights the development of a BBC arising within a keloid scar to the auricle region after an ear piercing 2 years prior. Keloidal characteristics often occur on the ear; however, there remain no reports of such a case within the literature. Given the sparse amount of evidence available, it is important for clinicians to understand and identify key keloidal features in BCCs and to reinforce the association of morphoeiform patterns of growth, ulceration, and necrosis as described by Jones et $\mathrm{al}^{10}$ Therefore, the authors stress the importance of considering early biopsy in any rapidly growing or changing keloidal scar.

\section{Acknowledgment}

The authors would like to thank the patient for her cooperation.

\section{Disclosure}

The authors report no conflicts of interest in this work.

\section{References}

1. Chung S. Basal cell carcinoma. Arch Plast Surg. 2012;39(2):166-170.

2. Rao J, Deora H. Surgical excision with forehead flap as single modality treatment for basal cell cancer of central face: single institutional experience of 50 cases. J Skin Cancer. 2014;2014:1-5.

3. Lim K-R, Cho K-H, Hwang S-M, Jung Y-H, Kim Song J. Basal cell carcinoma presenting as a hypertrophic scar. Arch Plast Surg. 2013;40(3): 289-291.

4. Sand M, Sand D, Brors D, Altmeyer P, Mann B, Bechara FG. Cutaneous lesions of the external ear. Head Face Med. 2008;4(2):1-13.

5. Requena L, Martin L, Farina MC, Pique E, Escalonilla P. Keloidal basal cell carcinoma. A new clinicopathological variant of basal cell carcinoma. Br J Dermatol. 1996;134(5):953-957.

6. Balestri R, Misciali C, Zampatti C, Odorici G, Balestri JA. Keloidal basal cell carcinoma: should it be considered a distinct entity? J Dtsch Dermatol Ges. 2013;11(12):1196-1198.
7. Nagashima K, Demitsu T, Nakamura T, et al. Keloidal basal cell carcinoma possibly developed from classical nodulo-ulcerative type of basal cell carcinoma: report of a case. J Dermatol. 2015;42(4):427-429.

8. Misago N, Ogusu Y, Narisawa Y. Keloidal basal cell carcinoma after radiation therapy. Eur J Dermatol. 2004;14(3):182-185.

9. Misago N. Keloidal basal cell carcinoma. Am J Dermatopathol. 2008; 30(1):87.

10. Jones M, Bresch M, Alvarez D, Böer A. Keloidal basal cell carcinoma: not a distinctive clinicopathological entity. Br J Dermatol. 2009;160(1): $127-131$

11. Tanaydin V, Beugels J, Piatkowski A, et al. Efficacy of custom-made pressure clips for ear keloid treatment after surgical excision. J Plast Reconstr Aesthet Surg. 2016;69(1):115-121.

12. Wilkins RH. Neurosurgical classic. XVII. J Neurosurg. 1964;21: 240-244.

13. He Y, Merin MR, Sharon VR, Maverakis E. Eruptive keloids associated with breast cancer: a paraneoplastic phenomenon? Acta Derm Venereol. 2011;91(4):480-481.

14. De Sousa RF, Chakravarty B, Sharma A, Parwaz MA, Malik A. Efficacy of triple therapy in auricular keloids. J Cutan Aesthet Surg. 2014;7(2): 98-102.

15. Del Toro D, Dedhia R, Tollefson TT. Advances in scar management: prevention and management of hypertrophic scars and keloids. Curr Opin Otolaryngol Head Neck Surg. 2016; Epub 2016 May 7.

16. Viera MH, Vivas AC, Berman B. Update on keloid management: clinical and basic science advances. Adv Wound Care. 2012;1(5):200-206.

17. Halim AS, Emami A, Salahshourifar I, Kannan TP. Keloid scarring: understanding the genetic basis, advances, and prospects. Arch Plast Surg. 2012;39(3):184-189.

18. Shin JY, Lee JW, Roh SG, Lee NH, Yang KM. A comparison of the effectiveness of triamcinolone and radiation therapy for ear keloids after surgical excision: a systematic review and meta-analysis. Plast Reconstr Surg. 2016;137(6):1718-1725.

19. Park TH, Rah DK. Successful eradication of helical rim keloids with surgical excision followed by pressure therapy using a combination of magnets and silicone gel sheeting. Int Wound J. 2015. Epub 2015 November 23.

20. Slemp AE, Kirschner RE. Keloids and scars: a review of keloids and scars, their pathogenesis, risk factors, and management. Curr Opin Pediatr. 2006;18(4):396-402.

21. Meade C, Smith S, Makhzoumi Z. Eruptive keloids associated with aromatase inhibitor therapy. JAAD Case Rep. 2015;1(3):112-113.
OncoTargets and Therapy

\section{Publish your work in this journal}

OncoTargets and Therapy is an international, peer-reviewed, open access journal focusing on the pathological basis of all cancers, potential targets for therapy and treatment protocols employed to improve the management of cancer patients. The journal also focuses on the impact of management programs and new therapeutic agents and protocols on

\section{Dovepress}

patient perspectives such as quality of life, adherence and satisfaction. The manuscript management system is completely online and includes a very quick and fair peer-review system, which is all easy to use. Visit http://www.dovepress.com/testimonials.php to read real quotes from published authors. 